\title{
The Effect of Heating of B20 Fuel to Combustion Characteristic on the Diesel Engine Based on Experiment
}

\author{
Semin $^{1}$, Beny Cahyono ${ }^{2}$, Faris M. Muhammad ${ }^{3}$, Barokah $^{4}$
}

(Received: 03 August 2019 / Revised: 24 November 2019 / Accepted: 28 November 2019)

\begin{abstract}
Bank Indonesia, the current account deficit of Indonesia. In the second quarter of 2018 increased to USD 8.0 billion. One of the government's programs to reduce the current account deficit is by implementing a B20 biodiesel policy. The increasing percentage of biodiesel in fuel blends tends to decrease the quality of spray atomization, where it indicated by longer droplet breakup, spray penetration, droplet lifetime, and bigger droplet diameter. Higher viscosity causes a decrease in the quality of the spray from the injector. Previous research shows that the inlet temperature of the fuel can make the performance of small diesel engines slightly better. The research was conducted using petrodiesel and biodiesel fuel by varying inlet temperature of $50^{\circ} \mathrm{C}$ and $70^{\circ} \mathrm{C}$. Based on that this research is conducted to understand the effect of fuel heating diesel engine combustion process. The result shows that generally maximum pressure is increased for every increase in fuel temperature. The heat release shows a decreasing trend for every increase in fuel temperature. Knock detection shows that generally when the fuel temperature increased the knocking is also increased. The increasing fuel temperature shows little effect on ignition delay except for the higher temperature of $60^{\circ} \mathrm{C}$ and $70^{\circ} \mathrm{C}$ where the ignition delay is the lowest and closest to that of a dexlite fuel.
\end{abstract}

Keywords-B20, biodiesel combustion process, fuel heating.

\section{INTRODUCTION}

According to Bank Indonesia, the current account deficit of Indonesia. In the second quarter of 2018 increased to USD 8.0 billion. One of the government's programs to reduce the current account deficit is by implementing a B20 biodiesel policy. This policy is expected to reduce oil imports and can save the national budget for imports, thus reducing the current account deficit. The policy officially replaces the pure diesel fuel (B0) with Bio Solar (B20) since September 1st, 2018 through ministerial decree 1936 K / 10 / MEM / 2018 about the procurement of biodiesel fuel starting from September 2018 [1].

Indonesia is the biggest producer of Crude Palm oil in the world, has a very good opportunity to produce biodiesel. Besides crude palm oil, there are some resources that can be used as a source of biodiesel like Jatropha with 557,842,000 barrels per year, algae with $258,867,000$ barrels per year and some other resources. It is predicted that with these supplies Indonesia can withstand the energy crisis up to 2101 [2]. Biodiesel fuel is already used as B20 fuel for general use for diesel

Semin, Departement of Marine Engineering, Institut Teknologi Sepuluh Nopember, Surabaya, 60111, Indonesia. E-mail: seminits@gmail.com

Beny Cahyono, Departement of Marine Engineering, Institut Teknologi Sepuluh Nopember, Surabaya, 60111, Indonesia. E-mail: benyjtsp98@gmail.com

Faris M. Muhammad, Departement of Marine Engineering, Institut Teknologi Sepuluh Nopember, Surabaya, 60111, Indonesia. E-mail: farismm29@gmail.com

Barokah, Politeknik Kelautan dan Perikanan Bitung, North Sulawesi, Indonesia. E-mail: barokahkarpov@yahoo.com engines from transportation to production. Starting from September $1^{\text {st }} 2018$, by ministerial decree $1936 \mathrm{~K} / 10 /$ MEM / 2018 about the procurement of biodiesel fuel from September, Indonesia started to effectively be commercialized the B20 fuel through several companies as producer and suppliers. This is done to reduce diesel fuel import budget for Indonesia.

Biodiesel fuel has advantages compared to diesel fuel. According to [3] these advantages are made from renewable sources, better emissions, and better lubricating property. The disadvantage of Biodiesel is more expensive than fossil fuel, less suitable for low temperatures, and has a higher viscosity than pure diesel fuel.

Biodiesel is chemically referred to as methyl ester or ethyl ester of fatty acids produced from plant vegetable oils or animal oils. Biodiesel derived from vegetable oil is made by converting triglycerides into fatty acids, using the catalyst in the esterification process. Biodiesel has the same physical and chemical properties as conventional diesel fuel. In general, biodiesel has an energy content that is almost close to diesel fuel. So it can be used to power engines for transportation and for agricultural purposes.

There are several factors like ignition delay, knocking, Rate of heat release, and pressure affecting the combustion process of the combustion chamber. Each of these factors is caused by different variables whether it's the fuel calorific value, fuel cetane number, fuel spray pattern, injection timing etc. All of those factors can affect the performance of the engine.

\section{METHOD}

\section{A. Ignition Delay}

Theoretically the combustion process in a diesel engine starts when the piston compresses the air in the combustion chamber, then when the piston reaches the 
Top Dead center, the fuel is injected which will burn by itself because the temperature of the combustion chamber has reached the flashpoint of the fuel. In fact there is a delay since the start of fuel injection with the occurrence of combustion. This delay is called Ignition delay [4].

The main reason for ignition delay depends on the cetane number $(\mathrm{CN})$ of the fuel used. Cetane number is a number that provides a measure of ignition characteristics of diesel fuel when it is burnt in the diesel engines. The fuel which has a lower cetane number has longer ignition delay characteristics [5].

\section{B. Maximum Pressure}

One of the factors of the combustion process is the pressure produced by the combustion. In the diesel engines, the peak pressure of the combustion chamber depends on the fraction of fuel burned during the premixed burning phase, i.e initial stage of combustion. The pressure of the cylinder characterizes the ability of the fuel to mix well in the air and burn [6].

\section{Rate of Heat Release}

The rate of heat release is defined as the heat released from a chemical in a given time. By knowing the heat release rate parameter, some of the combustion phenomena in the engine cylinder can be analyzed. Phenomena parameters such as combustion duration and intensity can be easily estimated from the heat release rate diagram [7]. The heat release rate and the diagram is shown in figure 1 and figure 2.

D. Knocking

Sometimes Diesel engines can experience abrupt cylinder pressure rise due to the rapid increase of fuel combustion rate. This is sometimes because of the fuel has longer ignition delay, the burning of the first droplets is longer, and more fuel is accumulated in the combustion chamber. Then when the ignition occurs, it burns violently and creates pressure oscillations. This phenomenon is called knocking [8].

There are several ways to improve engine performance. It is proven that by increasing the injection pressure there is an increase in engine power because of better combustion [9]. The second way to improve this is to add the number of nozzle holes for better spray distribution and improving the hole geometry of the nozzle. This way it is computationally proved that more nozzle hole and improved hole geometry have a better effect on the performance of a diesel engine [10]. This concept is also proven to be good on CNG marine Engines [11].

According to research conducted by [12]. In the research the fuel used was diesel fuel (B0) and up to Biodiesel (B100). In the research the combustion characteristic of both fuels was also analyzed. The result, was quite significant, by using Biodiesel (B100) the ignition delay is increased by 4 degrees and the total heat release is decreased until $26 \%$ compared to pure diesel fuel.

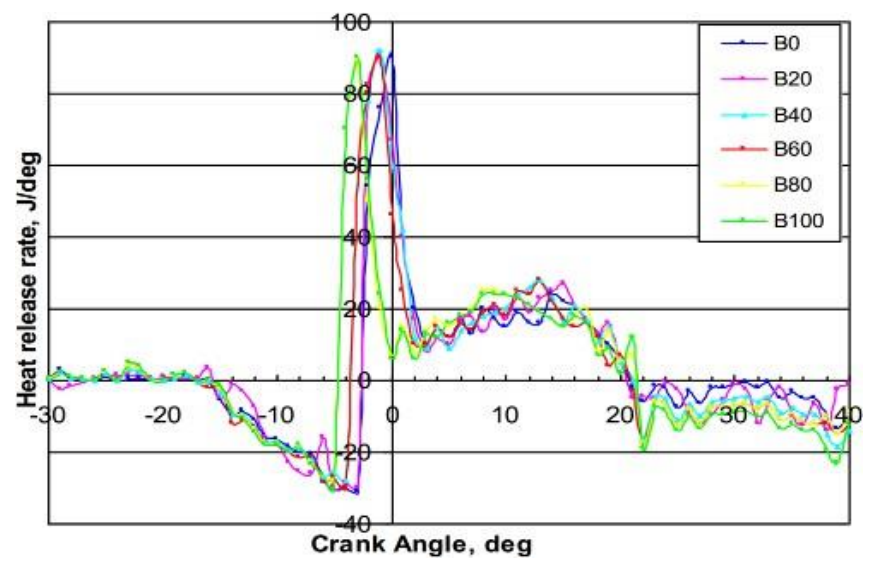

Figure. 1. Heat Release Rate Diagram diagram in the research [12]

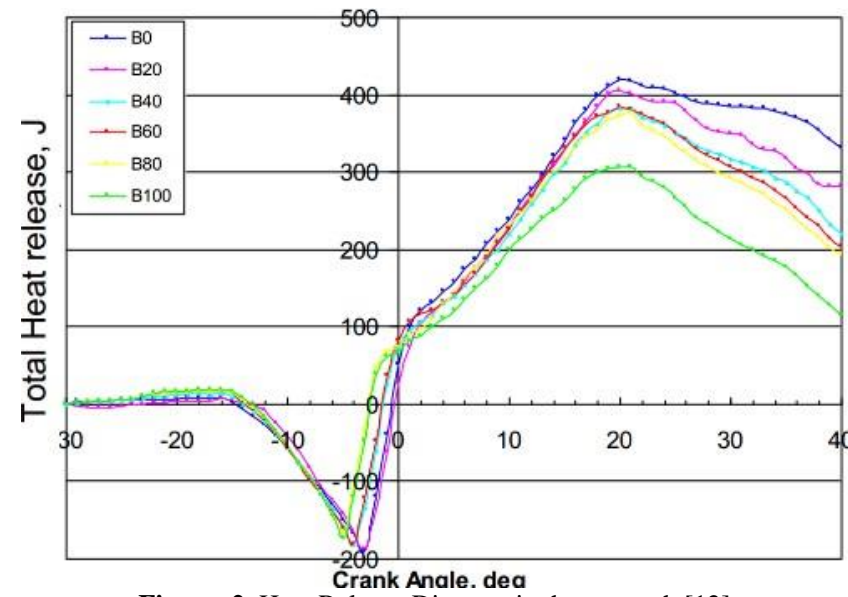

Figure. 2. Heat Release Diagram in the research [12] 
Research conducted by [13] proves that the inlet temperature of the fuel can make the performance of small diesel engine slightly better. The research was conducted using petrodiesel and biodiesel fuel by varying inlet temperature of $50^{\circ} \mathrm{C}$ and $70^{\circ} \mathrm{C}$ and observing the effect on engine brake thermal efficiency and brake specific fuel consumption.
The research shows that the effect of fuel temperature on brake thermal efficiency of the biodiesel at inlet temperature of ambient temperature, $50^{\circ} \mathrm{C}$ and $70^{\circ} \mathrm{C}$. It is shown that there is an increase of brake thermal efficiency as shown in the figure 3.

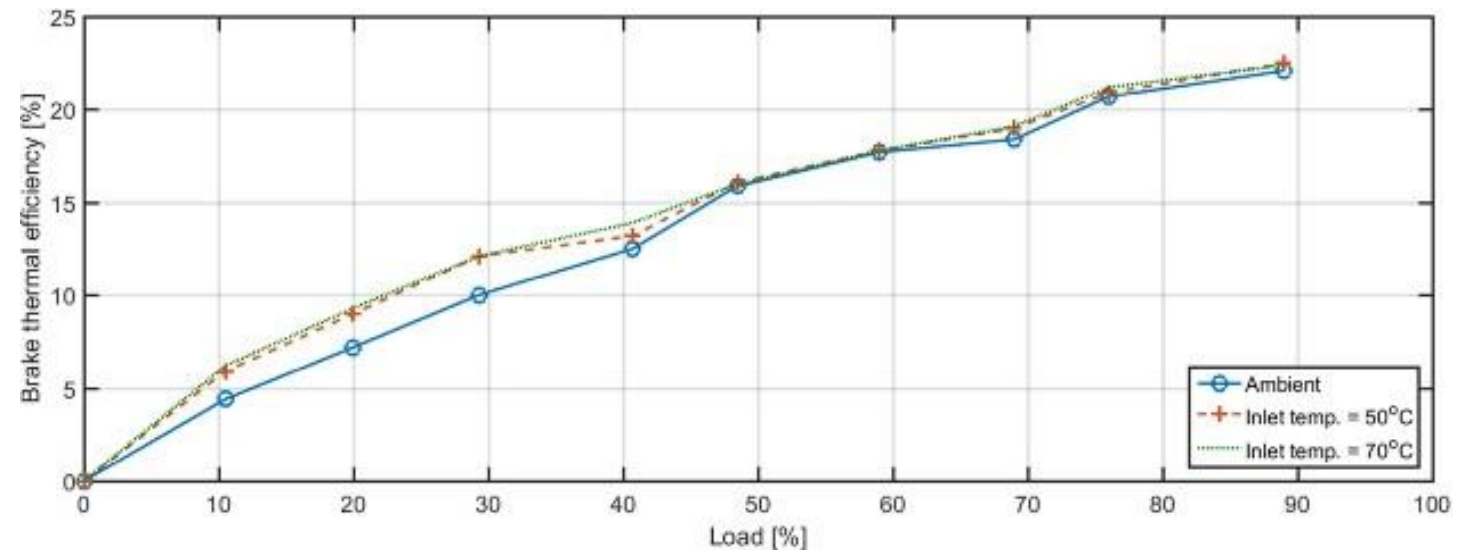

Figure. 3. Brake Thermal Efficiency vs load Graph [13].

The increase of Brake Thermal Efficiency is due to the weakening fuel chain hence better combustion can be achieved. With better combustion, it is expected that the performance of the engine is increased. On Brake
Specific Fuel Consumption (BSFC), there is a slight reduction of $\mathrm{BSFC}$ in both petrodiesel and Biodiesel at inlet temperature $70^{\circ} \mathrm{C}$ as shown in the figure 4 .

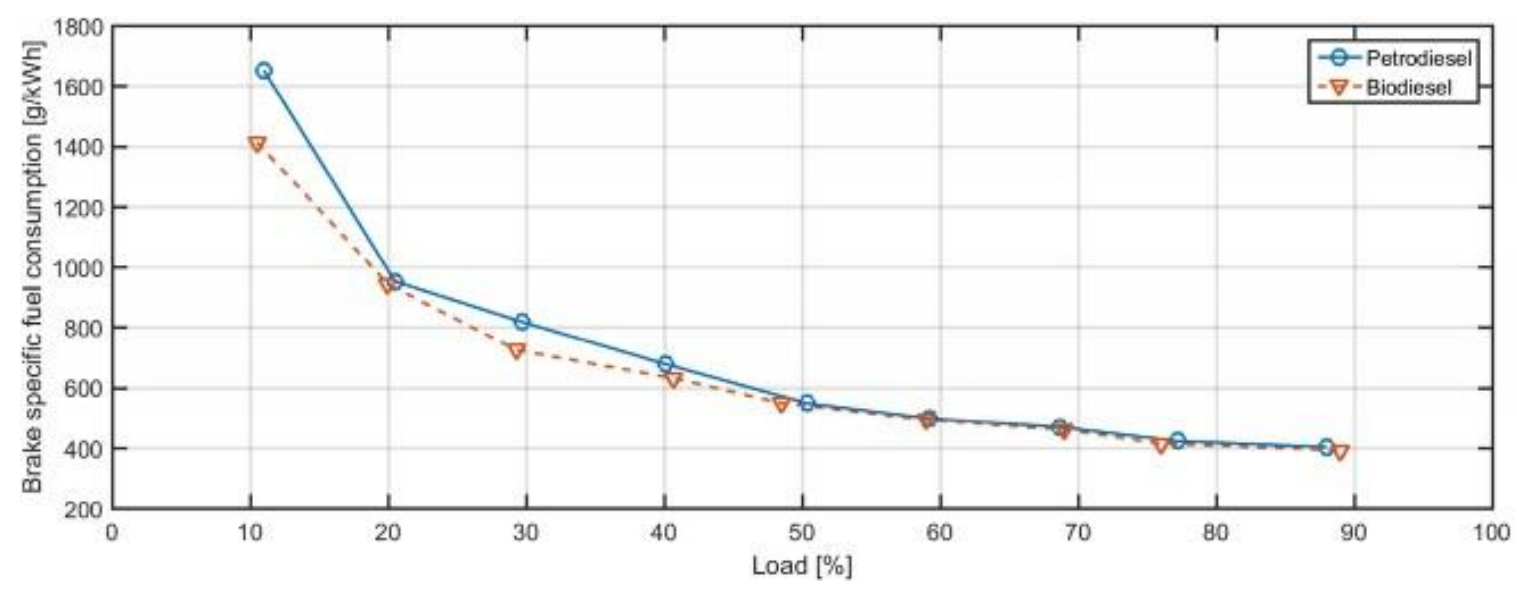

Figure. 4. Brake Specific Fuel Consumption vs Load [13].

Based on the research conducted by $[12,13]$ a further research needs to be conducted to seek the best inlet fuel temperature based on performance, spray characteristic and combustion characteristics. The research is also to be made with bigger diesel engine compared to the research

\section{RESULT AND DISCUSSIONS}

The engine ran at 1800 RPM and 2000 RPM with $100 \%$ load. The fuel heating is done by using a heat exchanger installed as a bypass on the engine cooling system. Fuel temperature is controlled by a solenoid valve which is controlled by a thermostat. The valve is located on the water intake of the heat exchanger.

The engine will be attached to a rotating encoder and pressure transducer which will be connected to done by [13] in order to see how much the effect of fuel preheating will take place. The effect of preheating can also be seen by doing combustion characteristic test on preheated fuel.

combustion analyzer. The data from combustion analyzer is taken from the prechamber/swirl-chamber of the engine. Analysis of combustion process is using TMRInstrument sensor and SYSMONSoft as data acquisition. Setup experiment can be seen in figure 5 and figure 6 . 
International Journal of Marine Engineering Innovation and Research, Vol. 5(1), Mar. 2020. 1-9 (pISSN: 2541-5972, eISSN: 2548-1479)

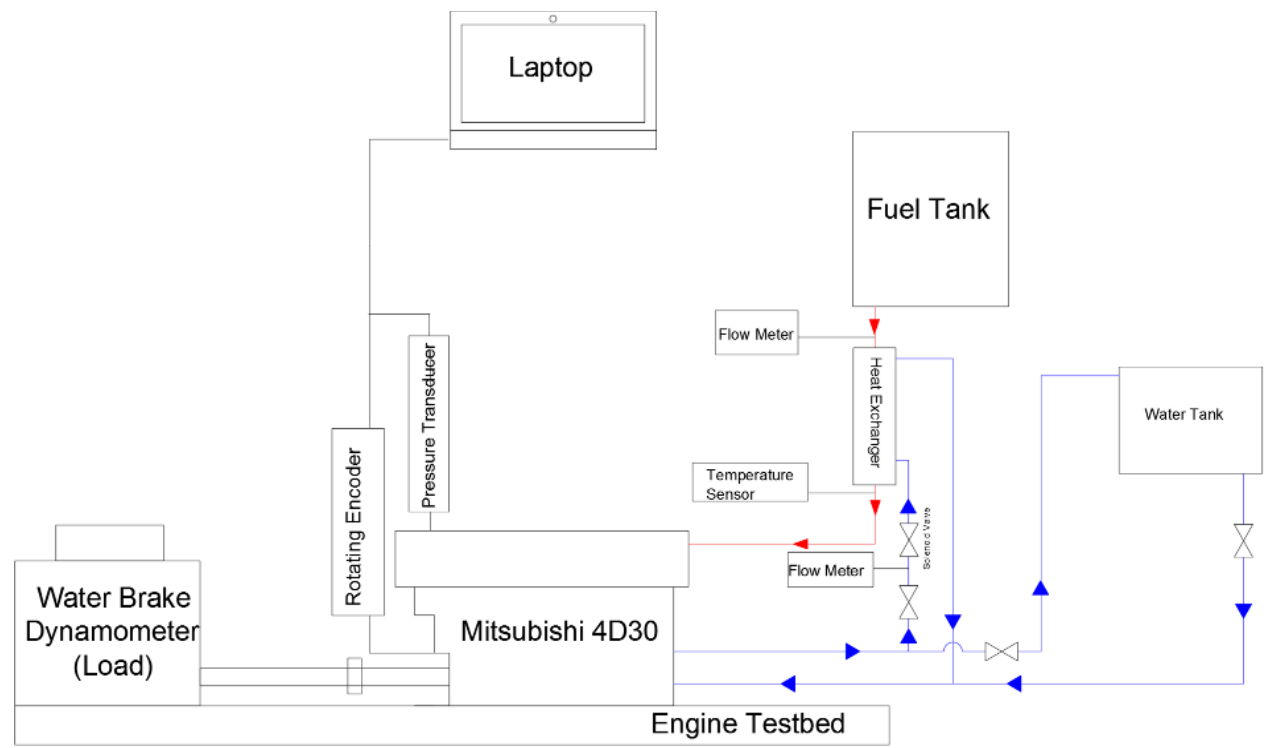

Figure. 5. Combustion characteristic test schematic setup.

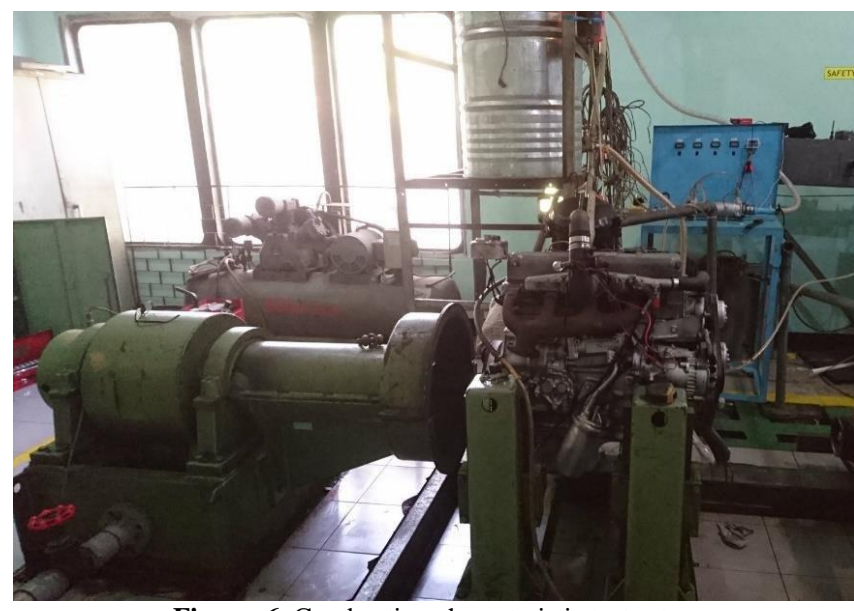

Figure. 6. Combustion characteristic test setup.

The fuel used in this experiment is B20 named "bio solar" which has widely used in Indonesia and as for comparison, B0 fuel is used named "dexlite". The specification for B20 is shown in table 1.

TABLE 1.

SPECIFICATION OF B20 "BiosolaR"

\begin{tabular}{|c|c|c|c|c|}
\hline \multirow[t]{2}{*}{ No } & \multirow[t]{2}{*}{ Characteristic } & \multirow[t]{2}{*}{ Units } & \multicolumn{2}{|c|}{ Limits } \\
\hline & & & Minimum & Maximum \\
\hline \multirow{2}{*}{1} & Cetane Number & - & 48 & - \\
\hline & Cetane Index & - & 45 & - \\
\hline 2 & Density @ $15^{\circ} \mathrm{C}$ & $\mathrm{Kg} / \mathrm{m}^{3}$ & 815 & 860 \\
\hline 3 & Viscosity @ $40^{\circ} \mathrm{C}$ & $\mathrm{mm}^{3} / \mathrm{sec}$ & 2.0 & 4.5 \\
\hline 4 & Sulphur Content & $\% \mathrm{~m} / \mathrm{m}$ & - & 0.25 \\
\hline 5 & Distilation $90 \%$ evaporation & ${ }^{\circ} \mathrm{C}$ & - & 370 \\
\hline 6 & Flash Point & ${ }^{\circ} \mathrm{C}$ & 52 & - \\
\hline 7 & Pour Point & ${ }^{\circ} \mathrm{C}$ & - & 18 \\
\hline 8 & Carbon Residue & $\% \mathrm{~m} / \mathrm{m}$ & - & 0.1 \\
\hline 9 & Water Content & $\mathrm{mg} / \mathrm{kg}$ & - & 500 \\
\hline 10 & Biological Growth & - & - & - \\
\hline 11 & FAME Content & $\% \mathrm{v} / \mathrm{v}$ & - & - \\
\hline 12 & Methanol Content & $\% \mathrm{v} / \mathrm{v}$ & - & - \\
\hline 13 & Ash Content & $\% \mathrm{v} / \mathrm{v}$ & - & 0.01 \\
\hline 14 & Sediment Content & $\% \mathrm{~m} / \mathrm{m}$ & - & 0.01 \\
\hline 15 & Strong Acid Number & $\mathrm{mgKOH} / \mathrm{gr}$ & - & 0 \\
\hline 16 & Total Acid Number & $\mathrm{mgKOH} / \mathrm{gr}$ & - & 0.6 \\
\hline 17 & Particulate & $\mathrm{mg} / \mathrm{l}$ & - & - \\
\hline 18 & Visual Appearance & - & Brig & clear \\
\hline 19 & Color & No.ASTM & - & 30 \\
\hline 20 & Lubricity & micron & - & 460 \\
\hline
\end{tabular}


International Journal of Marine Engineering Innovation and Research, Vol. 5(1), Mar. 2020. 1-9 (pISSN: 2541-5972, eISSN: 2548-1479)

The Engine that is used in the research is Mitsubishi 4D30. The engine specification is mentioned in table 2.

TABLE 2.

ENGINE SPECIFICATION

\begin{tabular}{llll}
\hline No. & \multicolumn{1}{c}{ Description } & \multicolumn{1}{c}{ Parameter } & Unit \\
\hline 1 & Manufacturer & Mitsubishi & \\
2 & Model & 4D30 & \\
3 & Type & $\begin{array}{l}\text { Inline 4, Water Cooled, } \\
\text { 4-stroke Diesel Engine }\end{array}$ & \\
& & Over Head Valve & \\
4 & Valve Mechanism & Swirl Chamber & \\
5 & Type of combustion chamber & $100 \times 105$ & $\mathrm{~mm}$ \\
6 & Bore x Stroke & 3298 & $\mathrm{cc}$ \\
7 & Displacement & 90 & $\mathrm{PS}$ \\
8 & Max Power & $22 @ 1800 \mathrm{RPM}$ & $\mathrm{kgfm}$ \\
9 & Max Torque & 120 & $\mathrm{Kg} / \mathrm{cm}^{2}$ \\
10 & Fuel Injection Pressure & $14^{\circ}$ & $\mathrm{BTDC}$ \\
\hline 11 & Injection Timing & & \\
\hline
\end{tabular}

\section{A. Maximum Pressure}

Figure 7 showing the maximum Pressure graph analysis at 1800 RPM for B20 fuel with fuel variation and dexlite as comparison. It can be observed that B20 fuel at $30^{\circ} \mathrm{C}$ can achieve 41.71 bar of maximum pressure at $7^{\circ}$ angle after TDC. Then $\mathrm{B} 20$ at $40^{\circ} \mathrm{C}$ can achieve
42.34 bar of maximum pressure at $7^{\circ}$ angle after TDC. For $\mathrm{B} 20$ at $50^{\circ} \mathrm{C}$ can achieve 41.96 bar of maximum pressure at $8^{\circ}$ angle after TDC. B20 at $60^{\circ} \mathrm{C}$ can achieve 43.09 bar of maximum pressure at $8^{\circ}$ angle after TDC.

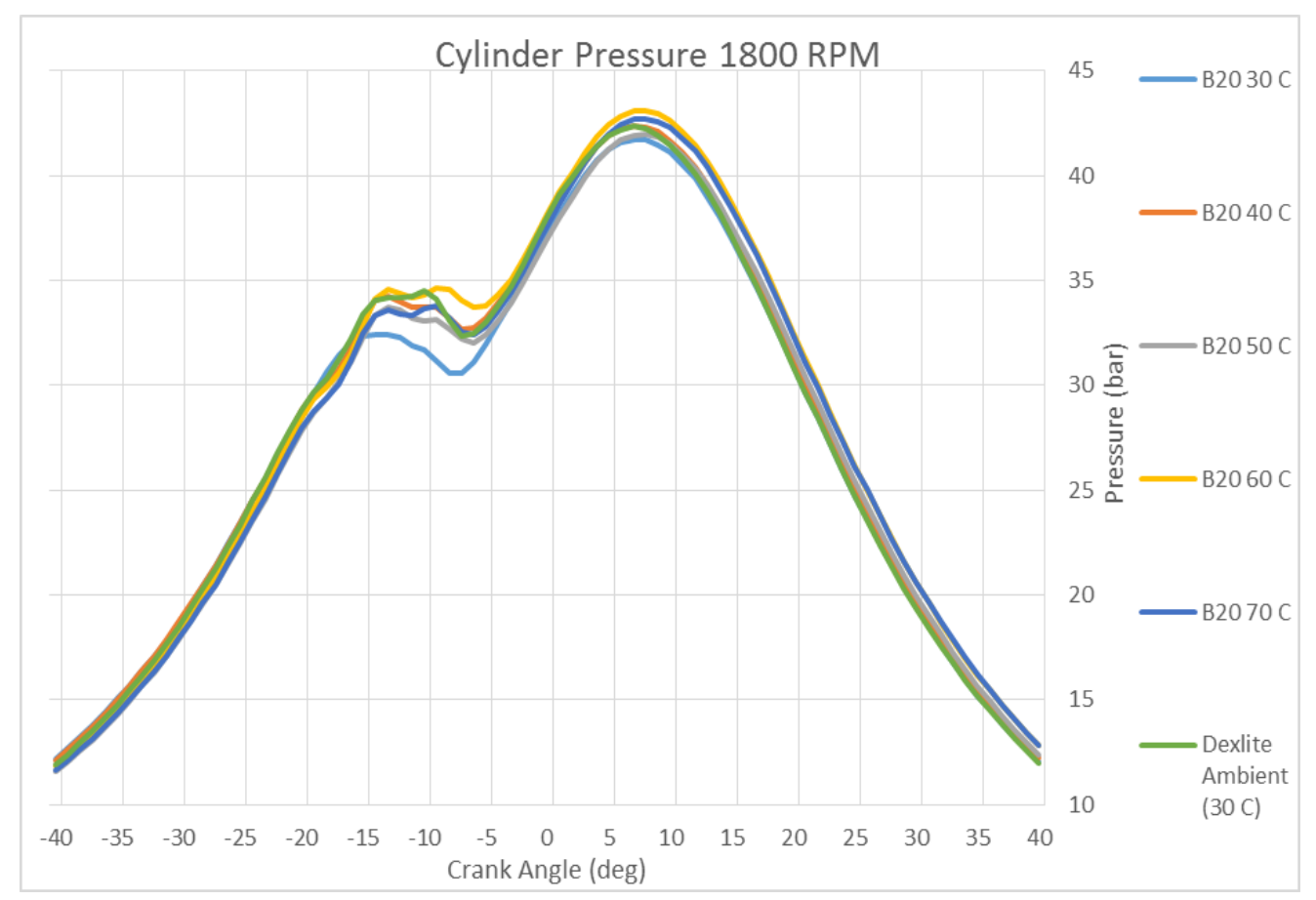

Figure. 7. Maximum Pressure Graph.

Then $\mathrm{B} 20$ at $70^{\circ} \mathrm{C}$ can achieve 42.71 bar of maximum pressure at $8^{\circ}$ angle after TDC. As for comparison dexlite can achieve 42.33 bar of maximum pressure at $7^{\circ}$ angle after TDC. The value of Maximum Pressure and the angle it's achieve is depending on how long the fuel burnt and the ignition delay time. The longer the ignition delay time means the topmost point will be having more distance from the injection point at $14^{\circ}$ before TDC. 


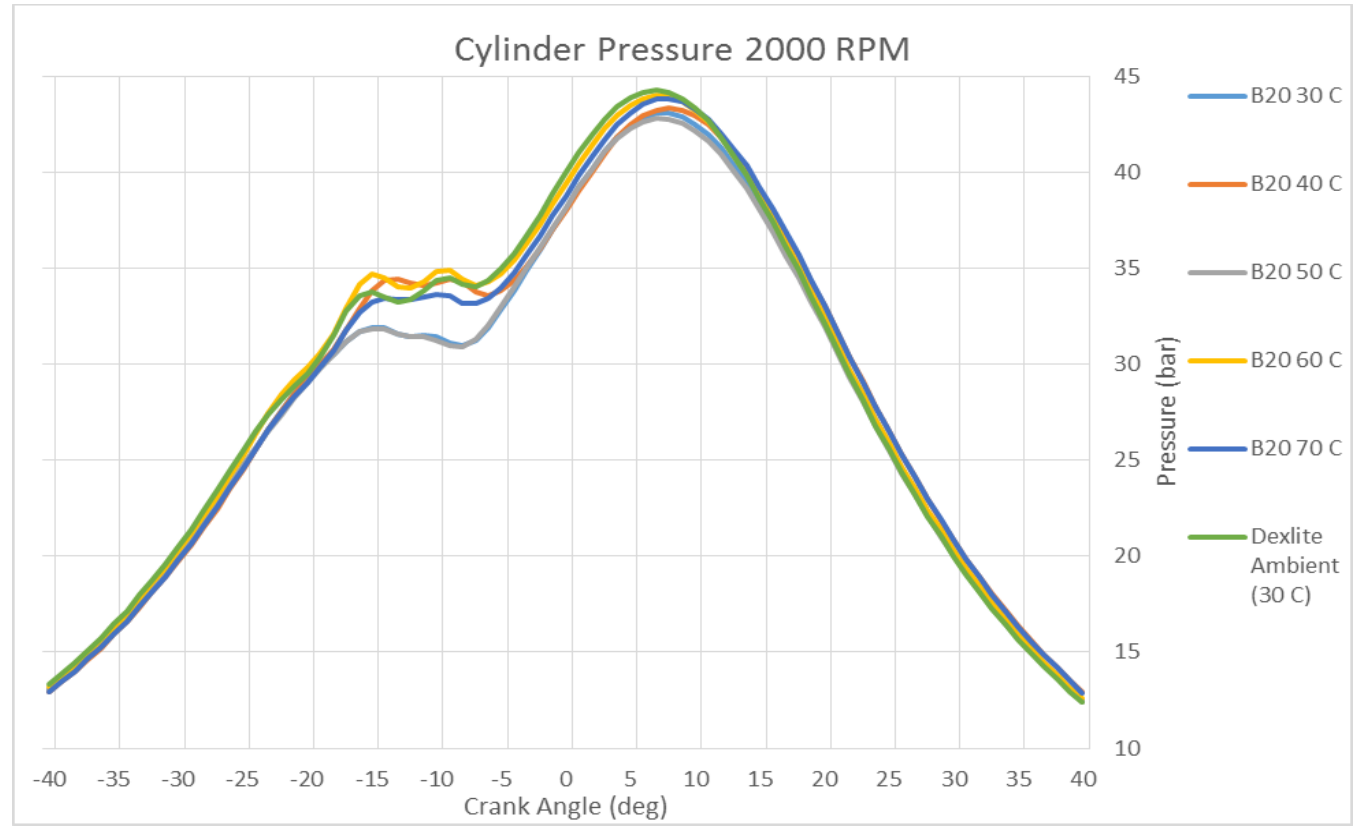

Figure. 8. Maximum Pressure Graph.

Figure 8 is showing the max Pressure graph analysis at 2000 RPM for B20 fuel with fuel variation and dexlite as comparison. It can be observed that $\mathrm{B} 20$ fuel at $30^{\circ} \mathrm{C}$ can achieve 43.07 bar of maximum pressure at $8^{\circ}$ angle after TDC. Then $\mathrm{B} 20$ at $40^{\circ} \mathrm{C}$ can achieve 43.30 bar of maximum pressure at $8^{\circ}$ angle after TDC. For B20 at $50^{\circ} \mathrm{C}$ can achieve 42.81 bar of maximum pressure at $7^{\circ}$ angle after TDC. B20 at $60^{\circ} \mathrm{C}$ can achieve 44.0 bar of maximum pressure at $7^{\circ}$ angle after TDC. Then B20 at $70^{\circ} \mathrm{C}$ can achieve 43.82 bar of maximum pressure at $8^{\circ}$

\section{B. Rate of Heat Release}

From Figure 9 the result can be known. From Rate of heat release graph ignition delay can be known. The injection timing for Mitsubishi 4D30 is $14^{\circ}$ before TDC. It then can be observed that $\mathrm{B} 20$ at $30^{\circ} \mathrm{C}$ has earliest combustion at $2^{\circ}$ before TDC and has highest heat release at $11^{\circ}$ after TDC with the value of 27.05 angle after TDC. As for comparison dexlite can achieve 44.30 bar of maximum pressure at $7^{\circ}$ angle after TDC. The value of Maximum Pressure and the angle it's achieve is depending on how long the fuel burnt and the ignition delay time. The longer the ignition delay time means the topmost point will be having more distance from the injection point at $14^{\circ}$ before TDC.

$\mathrm{kJ} / \mathrm{m}^{3} / \mathrm{deg}$. Then $\mathrm{B} 20$ at $40^{\circ} \mathrm{C}$ has earliest combustion at $2^{\circ}$ before TDC and has highest heat release at $10^{\circ}$ after TDC with the value of $20.84 \mathrm{~kJ} / \mathrm{m}^{3} / \mathrm{deg}$. Then B20 at $50^{\circ} \mathrm{C}$ has earliest combustion at $3^{\circ}$ before TDC and has highest heat release at $11^{\circ}$ after TDC with the value of $25.21 \mathrm{~kJ} / \mathrm{m}^{3} / \mathrm{deg}$.

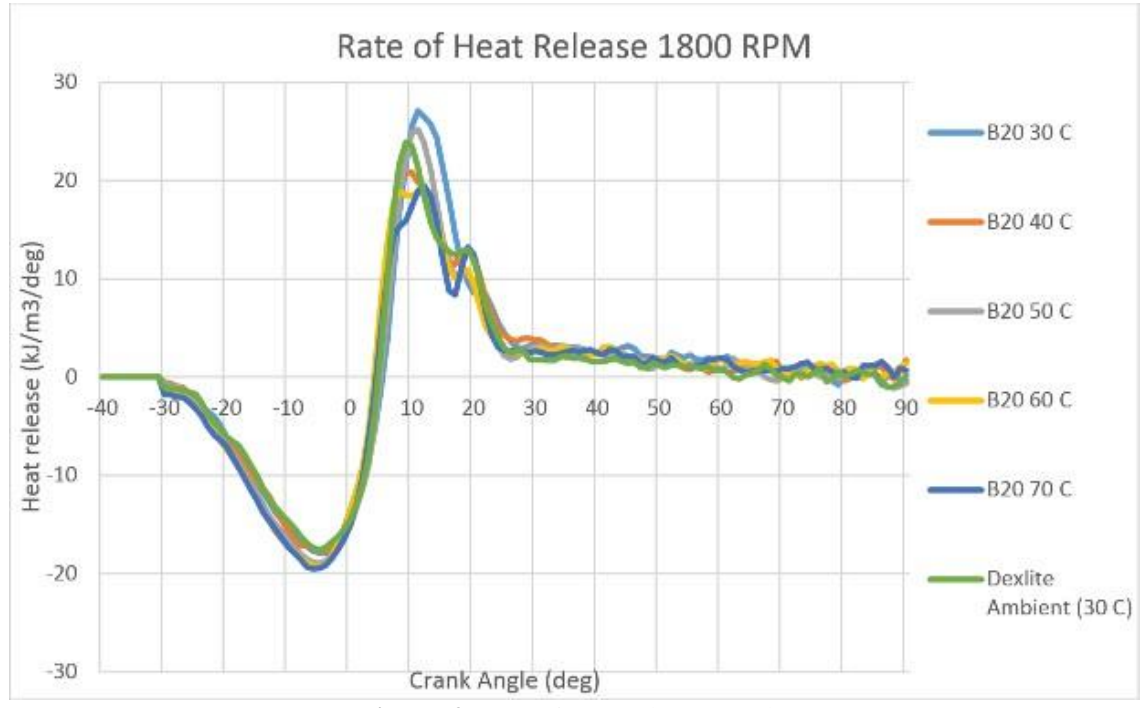

Figure. 9. Rate of Heat release Graph.

Then $\mathrm{B} 20$ at $60^{\circ} \mathrm{C}$ has earliest combustion at $3^{\circ}$ before TDC and has highest heat release at $8^{\circ}$ after TDC with the value of $18.9 \mathrm{~kJ} / \mathrm{m}^{3} / \mathrm{deg}$. Then $\mathrm{B} 20$ at $70^{\circ} \mathrm{C}$ has earliest combustion at $3^{\circ}$ before TDC and has highest 
heat release at $12^{\circ}$ after TDC with the value of 19.46 $\mathrm{kJ} / \mathrm{m}^{3} / \mathrm{deg}$. Then Dexlite for comparison has earliest combustion at $4^{\circ}$ before TDC and has highest heat release at $9^{\circ}$ after TDC with the value of $23.9 \mathrm{~kJ} / \mathrm{m}^{3} / \mathrm{deg}$.

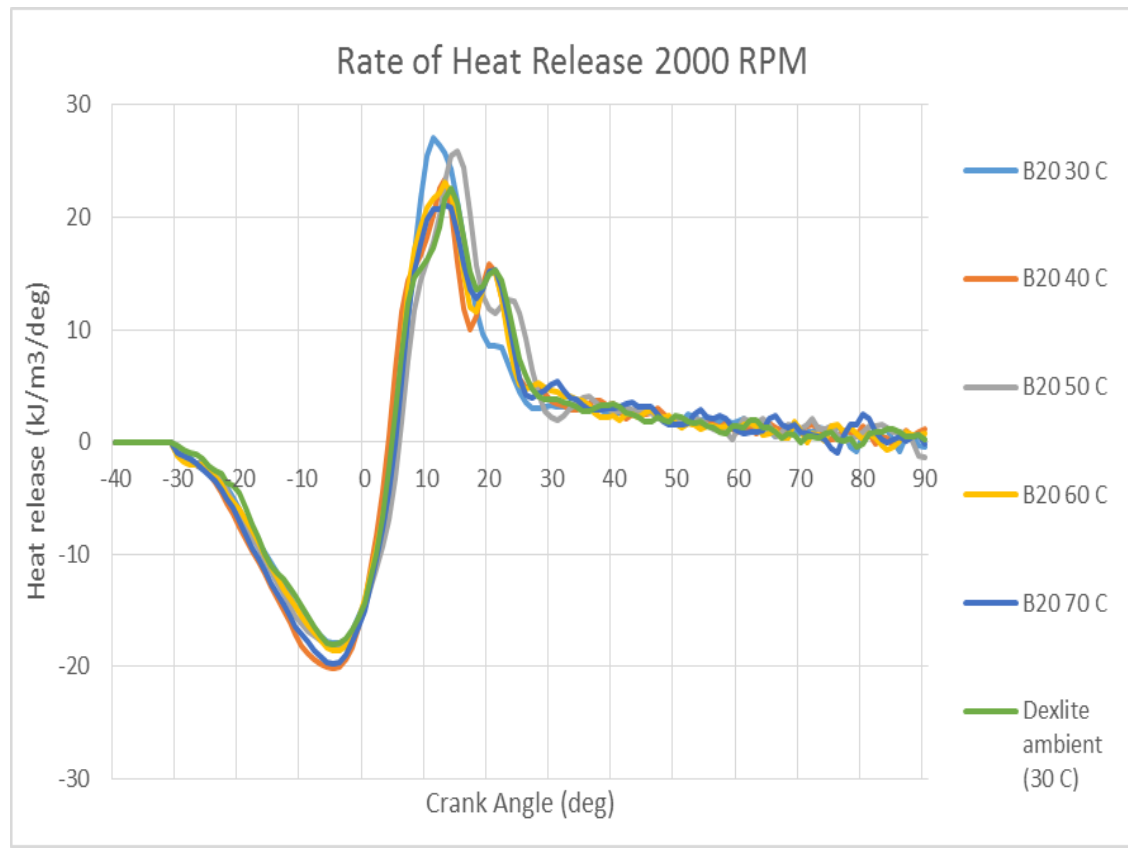

Figure. 10. Rate of Heat release Graph.

From the Figure 10 the result can be known. From Rate of heat release graph ignition delay can be known. The injection timing for Mitsubishi 4D30 is $14^{\circ}$ before TDC. It then can be observed that $\mathrm{B} 20$ at $30^{\circ} \mathrm{C}$ has earliest combustion at $3^{\circ}$ before TDC and has highest heat release at $11^{\circ}$ after TDC with the value of 27.41 $\mathrm{kJ} / \mathrm{m}^{3} / \mathrm{deg}$. Then $\mathrm{B} 20$ at $40^{\circ} \mathrm{C}$ has earliest combustion at $2^{\circ}$ before TDC and has highest heat release at $13^{\circ}$ after TDC with the value of $23.35 \mathrm{~kJ} / \mathrm{m}^{3} / \mathrm{deg}$. Then B20 at $50^{\circ} \mathrm{C}$ has earliest combustion at $1^{\circ}$ before TDC and has highest heat release at $15^{\circ}$ after TDC with the value of

\section{Knock Detection}

Figure 11 is the knock Detection graph analysis at 1800 RPM. The graph shown the knock detection for B20 inlet temperature ranging from $30^{\circ} \mathrm{C}$ to $70^{\circ} \mathrm{C}$ and Dexlite for comparison. $\mathrm{B} 20$ fuel at $30^{\circ} \mathrm{C}$ has highest
$25.95 \mathrm{~kJ} / \mathrm{m}^{3} / \mathrm{deg}$. Then $\mathrm{B} 20$ at $60^{\circ} \mathrm{C}$ has earliest combustion at $3^{\circ}$ before TDC and has highest heat release at $13^{\circ}$ after TDC with the value of $23.1 \mathrm{~kJ} / \mathrm{m}^{3} / \mathrm{deg}$. Then B20 at $70^{\circ} \mathrm{C}$ has earliest combustion at $4^{\circ}$ before TDC and has highest heat release at $15^{\circ}$ after TDC with the value of $25.16 \mathrm{~kJ} / \mathrm{m}^{3} / \mathrm{deg}$. Then Dexlite for comparison has earliest combustion at $4^{\circ}$ before TDC and has highest heat release at $14^{\circ}$ after TDC with the value of 22.62 $\mathrm{kJ} / \mathrm{m}^{3} /$ deg.

point of knocking at 0.82 at $7^{\circ}$ after TDC. B20 fuel at $40^{\circ} \mathrm{C}$ has highest point of knocking at 0.96 at $14^{\circ}$ after TDC.

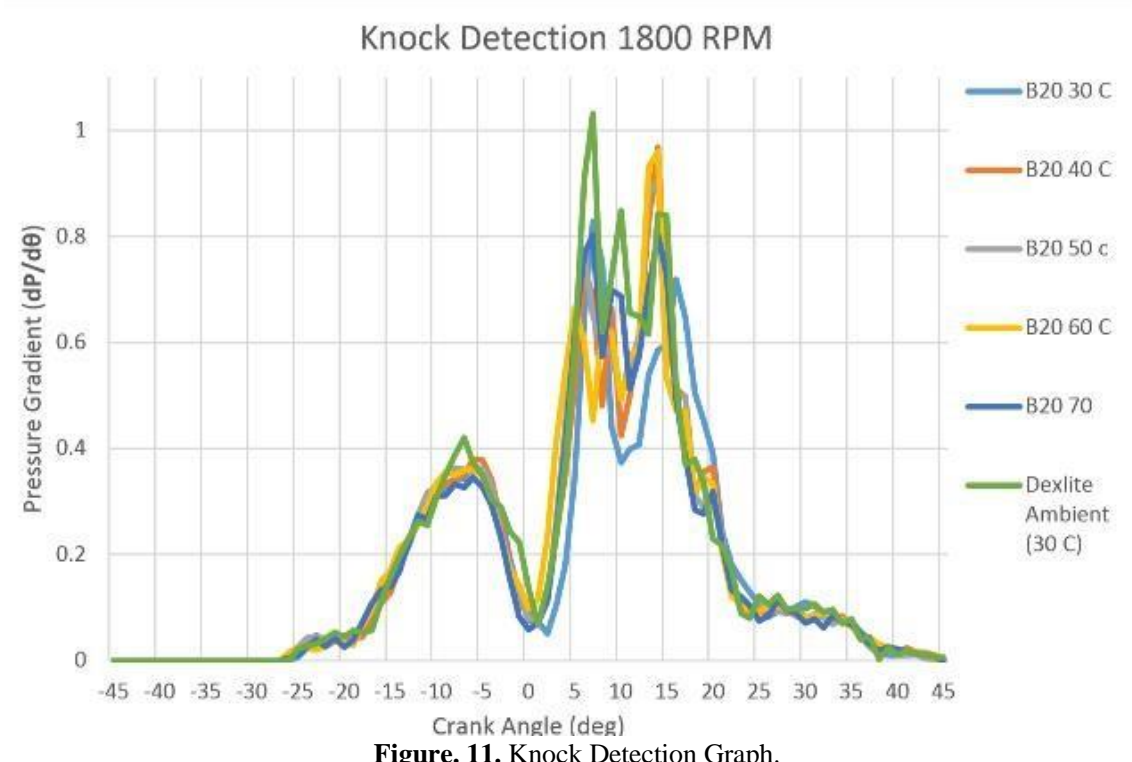

Figure. 11. Knock Detection Graph. 
The B20 fuel at $50^{\circ} \mathrm{C}$ has highest point of knocking at 0.90 at $14^{\circ}$ after TDC. B20 fuel at $60^{\circ} \mathrm{C}$ has highest point of knocking at 0.96 at $14^{\circ}$ after TDC. B20 fuel at $70^{\circ} \mathrm{C}$ has highest point of knocking at 0.80 at $14^{\circ}$ after TDC. Dexlite for comparison has highest point of knocking at 1.03 at $7^{\circ}$ after TDC.

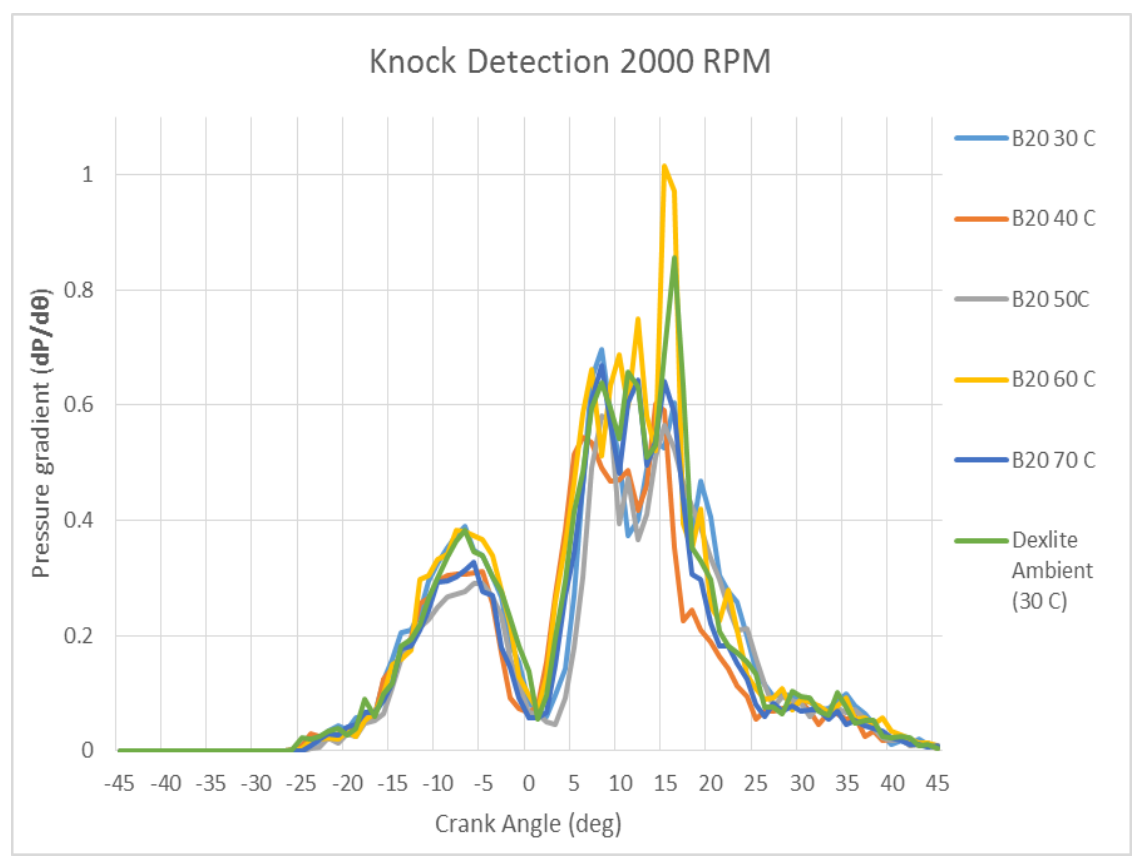

Figure. 12. Knock Detection Graph.

Figure 12 is the knock Detection graph analysis at 2000 RPM. The graph shown the knock detection for B20 inlet temperature ranging from $30^{\circ} \mathrm{C}$ to $70^{\circ} \mathrm{C}$ and Dexlite for comparison. $\mathrm{B} 20$ fuel at $30^{\circ} \mathrm{C}$ has highest point of knocking at 0.69 at $8^{\circ}$ after TDC. B20 fuel at $40^{\circ} \mathrm{C}$ has highest point of knocking at 0.60 at $14^{\circ}$ after TDC. B20 fuel at $50^{\circ} \mathrm{C}$ has highest point of knocking at

\section{Ignition Delay}

Figure 13 is showing the ignition delay of B20 fuel for every inlet temperature. The ignition delay for B20 at $30^{\circ} \mathrm{C}$ inlet temperature is $1.111 \mathrm{~ms}$. Ignition delay for $\mathrm{B} 20$ at $40^{\circ} \mathrm{C}$ inlet temperature is $1.111 \mathrm{~ms}$. Ignition delay for $\mathrm{B} 20$ at $50^{\circ} \mathrm{C}$ inlet temperature is $1.018 \mathrm{~ms}$. Ignition
0.58 at $8^{\circ}$ after TDC. $\mathrm{B} 20$ fuel at $60^{\circ} \mathrm{C}$ has highest point of knocking at 1.01 at $15^{\circ}$ after TDC. B20 fuel at $70^{\circ} \mathrm{C}$ has highest point of knocking at 0.66 at $8^{\circ}$ after TDC. Dexlite for comparison has highest point of knocking at 0.85 at $16^{\circ}$ after TDC.

delay for $\mathrm{B} 20$ at $60^{\circ} \mathrm{C}$ inlet temperature is $1.018 \mathrm{~ms}$. Ignition delay for $\mathrm{B} 20$ at $70^{\circ} \mathrm{C}$ inlet temperature is 1.018 ms. While Dexlite achieve the lowest ignition delay at $0.925 \mathrm{~ms}$.

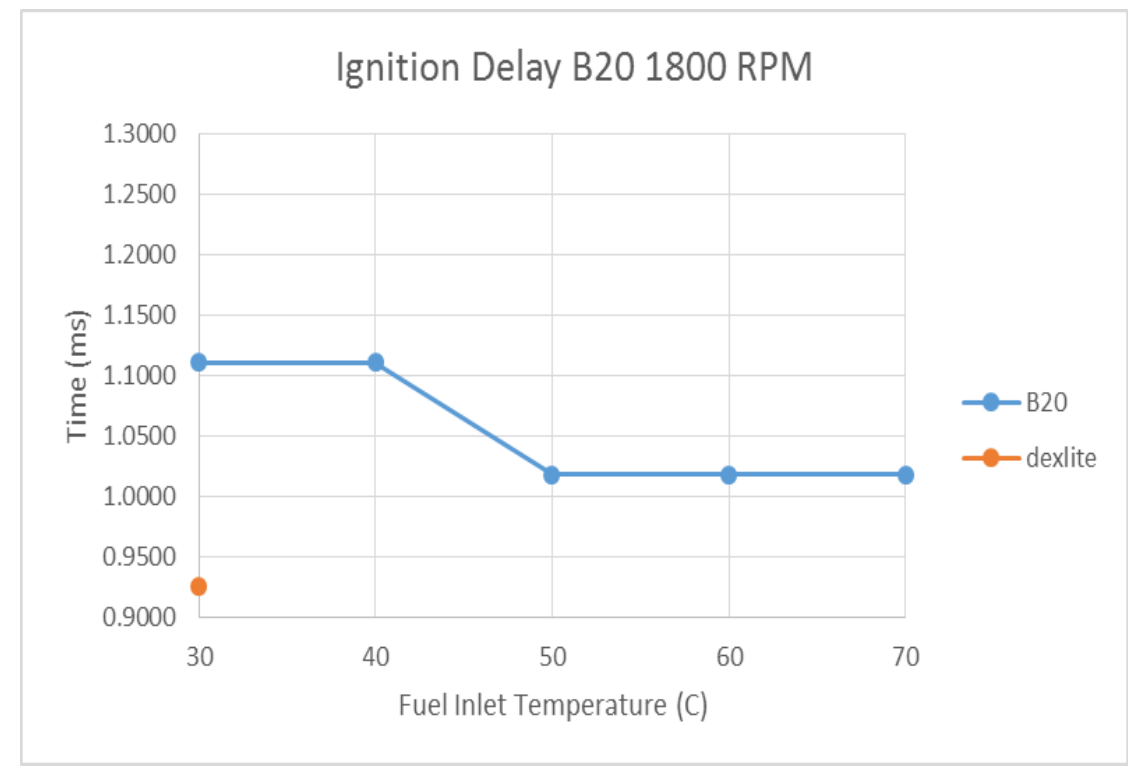

Figure. 13. Ignition Delay Graph. 
Ignition delay time depends on the value of cetane number of the fuel. The higher the cetane number of a fuel, the faster the time takes for the fuel to ignite. There fore higher cetane number means shorter ignition delay. In this case Dexlite has shorter ignition delay. This is due to the fact that Dexlite has cetane number of

51. While B20 (Biosolar) has cetane number of 48 .

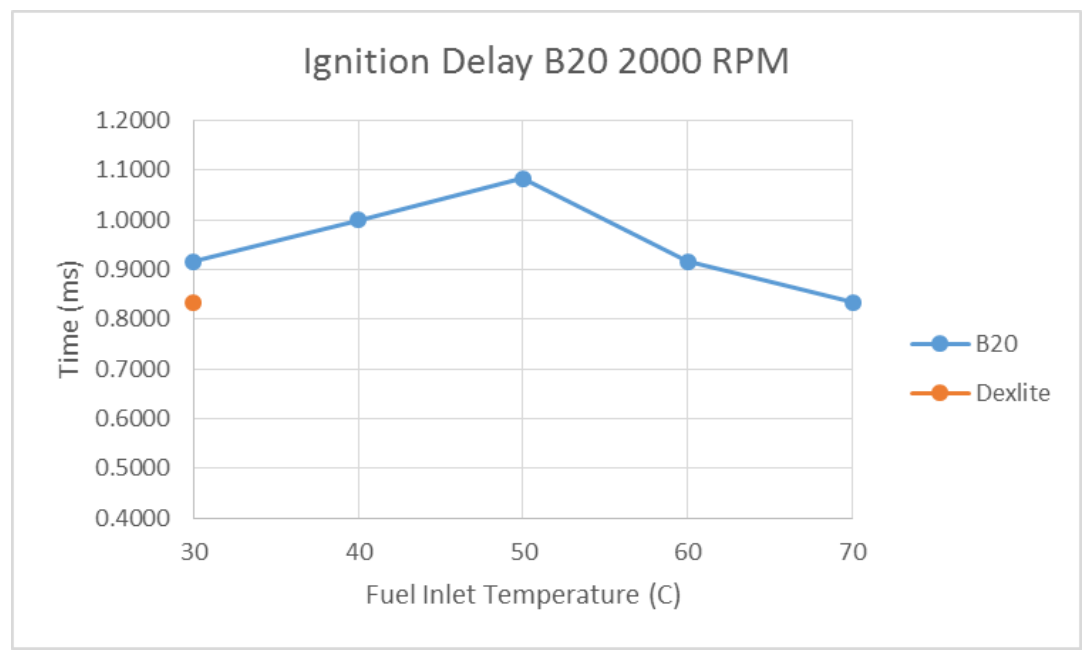

Figure. 14. Ignition Delay Graph.

Figure 14 is showing the ignition delay of B20 fuel for every inlet temperature. The ignition delay for B20 at $30^{\circ} \mathrm{C}$ inlet temperature is $0.916 \mathrm{~ms}$. Ignition delay for $\mathrm{B} 20$ at $40^{\circ} \mathrm{C}$ inlet temperature is $1 \mathrm{~ms}$. Ignition delay for $\mathrm{B} 20$ at $50^{\circ} \mathrm{C}$ inlet temperature is $1.083 \mathrm{~ms}$. Ignition delay for $\mathrm{B} 20$ at $60^{\circ} \mathrm{C}$ inlet temperature is $0.916 \mathrm{~ms}$. Ignition delay for $\mathrm{B} 20$ at $70^{\circ} \mathrm{C}$ inlet temperature is $0.833 \mathrm{~ms}$. While Dexlite achieve the lowest ignition delay at 0.833 ms.

Ignition delay time depends on the value of cetane number of the fuel. the higher the cetane number of a fuel, the faster the time takes for the fuel to ignite. There fore higher cetane number means shorter ignition delay. In this case Dexlite has shorter ignition delay. This is due to the fact that Dexlite has cetane number of

51. While B20 (Biosolar) has cetane number of 48 .

\section{CONCLUSIONS}

B20 Temperature can affect the combustion characteristics with detail as follows:

- Based on Maximum pressure graph, it is shown that there is an increasing trend of pressure when the fuel inlet temperature is increased. But the trend goes downward on high temperatures like $60^{\circ} \mathrm{C}$ and $70^{\circ} \mathrm{C}$. The result also shows that there is little effect on the crank angle of highest pressure is achieved. The highest pressure is always achieved at 7 to 8 degrees after TDC.

- Based on Heat Release rate graph, it is shown that there is decreasing trend on the peak value of heat release rate for when the fuel inlet temperature is increased. This is due to the fact that increasing temperature of fuel inlet causing the fuel density to goes down while the plunger of the injection system has the same volume, so the fuel mass per injection goes into the combustion chamber goes down. The result also shows that mostly the crank angle of highest heat release rate is longest when the fuel inlet temperature is $50^{\circ} \mathrm{C}$ for every RPM.
- Based on Knock Detection Graph, it is shown that the knocking is generally higher when the temperature of the fuel inlet is increased. The crank angle of the highest point of knocking is varied between first peak at $7^{\circ}-8^{\circ}$ Before TDC or $14^{\circ}-15^{\circ} \mathrm{C}$ after TDC.

- Based on Ignition delay graph, it is shown that the temperature increaseonly give a slight effect on ignition delay. The closest temperature and condition to approach the value of dexlite is at higher temperatures of $60^{\circ} \mathrm{C}$ to $70^{\circ} \mathrm{C}$.

\section{REFERENCES}

[1] Kementrian ESDM. "Keputusan Menteri Energi Dan Sumber Daya Mineral Republik Indonesia Nomor 1936 K/10/Mem/2018". Kementrian ESDM Republik Indonesia. (2018)

[2] Kuncahyo, P., Fathallah. A,Z,M., \& Semin (2013). JURNAL TEKNIK POMITS vol.2 (1) (2013)

[3] Viesturs, Dainis and Ligita Melece. "Advantages and Disadvantages of Biofuels: Observations in Latvia". Latvia University of Agriculture (2014)

[4] Siagian, A., Silaban, M. Jurnal Teknik Mesin Petra. Vol.14 (1). (2013)

[5] Rabl, S., Davies, T.J., McDougall, A.P., \& R.F Cracknell. Proceedings of the Combustion Institute Vol 35 (3). (2014).

[6] Qi, D. e. Energy Conversion and Management 51, 2985 2992. (2010).

[7] Tesfa, B.et al. RE\&PGJ, Vol.1, No.9. (2011).

[8] Lasocki, J. Proceedings of the Institute Of Vehicles 5 (109).(2016).

[9] Bakar, R.A., Semin., Ismail, A.R. American Journal of Applied Sciences 5 (3): 197-202, (2008)

[10] Bakar, R.A., Semin., Abdul, R., Ismail A. American Journal of Applied Sciences 5 (2): 110-116. (2008)

[11] Semin., Beny Cahyono., Amiadji., \& R.A Bakar. Procedia Earth and Planetary Science 14(14):101-109. (2014)

[12] Sudarmanta, B., Rachimoellah, M., Winardi, S., Sungkono, D. RSCE 7. (2007).

[13] Bin-Mahfouz, A., Mahmoud, K., \& Mourad, M. AASCIT Vol. 5,(3):42-48. (2018). 